\title{
Otolith geochemistry does not reflect dispersal history of clownfish larvae
}

ML Berumen ${ }^{1,2,3}$ ), HJ Walsh ${ }^{2}, \mathrm{~N}_{\text {Raventos }}{ }^{4}$, S Planes ${ }^{5}$, GP Jones ${ }^{3,6}$, V Starczak ${ }^{2}$, SR Thorrold ${ }^{2}$

1. Red Sea Research Center, King Abdullah University of Science and Technology, Thuwal, 23955-6900, Kingdom of Saudi Arabia

2. Biology Department, Woods Hole Oceanographic Institution, Woods Hole, MA 02543, USA

3. ARC Centre of Excellence for Coral Reef Studies, James Cook University, Townsville, QLD 4811, Australia

4. Centro de Estudios Avanzados de Blanes, Consejo Superior de Investigaciones Cientificas, Camino Acceso a la Cala San Francesc, 14, Blanes 17300, Girona, Spain

5. USR 3278 CNRS EPHE, Center de Recherches Insulaires et Observatoire de l'Environnement (CRIOBE), BP 1013 Papetoai, 98729 Moorea, French Polynesia

6. School of Marine and Tropical Biology, James Cook University, Townsville, QLD 4811, Australia

) Corresponding author:

Email: mberumen@whoi.edu

Phone: +1 508-289-3963

Fax: +1 508-457-2089

Keywords: Amphiprion percula; connectivity; natural markers; otolith chemistry; Papua New Guinea; pelagic larval duration 


\begin{abstract}
Natural geochemical signatures in calcified structures are commonly employed to retrospectively estimate dispersal pathways of larval fish and invertebrates. However, the accuracy of the approach is generally untested due to the absence of individuals with known dispersal histories. We used genetic parentage analysis (genotyping) to divide 110 new recruits of the orange clownfish, Amphiprion percula, from Kimbe Island, Papua New Guinea, into two groups: "self-recruiters" spawned by parents on Kimbe Island and "immigrants" that had dispersed from distant reefs ( $>10 \mathrm{~km}$ away). Analysis of daily increments in sagittal otoliths found no significant difference in PLDs or otolith growth rates between self-recruiting and immigrant larvae. We also quantified otolith $\mathrm{Sr} / \mathrm{Ca}$ and $\mathrm{Ba} / \mathrm{Ca}$ ratios during the larval phase using laser ablation inductively coupled plasma mass spectrometry. Again, we found no significant differences in larval profiles of either element between self-recruits and immigrants. Our results highlight the need for caution when interpreting otolith dispersal histories based on natural geochemical tags in the absence of water chemistry data or known-origin larvae with which to test the discriminatory ability of natural tags.
\end{abstract}




\section{Introduction}

Larval dispersal is a critical feature of the ecology of most marine organisms, particularly for reef species with limited adult movement. While understanding the nature, pattern, and extent of this dispersal is a key for science-based management of reef fish populations, obtaining direct estimates of this information is not easy (Gaines et al. 2007). The primary difficulty lies in identifying natal origins of newly settling individuals because tracking larvae of many marine species is a major challenge (Levin 2006). Tracking the pelagic larval stage of coral reef fishes is particularly challenging due to the typical number and size of larvae produced, the high mortality of newly hatched larvae, the length of their pelagic stage (often several weeks), and their capacity to interact with the physical environment through the use of sensory and behavioral abilities (Cowen et al. 2007; Thorrold et al. 2007).

Numerous approaches to address the question of tracking larvae in marine environments have been explored (Thorrold et al. 2002). Natural geochemical tags in calcified structures that form during embryogenesis, including otoliths, shells and statoliths, have shown particular promise (e.g., Swearer et al. 1999; Zacherl et al. 2003; Becker et al. 2005). Fish otoliths (earbones) have long been recognized for their utility in age estimation of fishes (Campana and Thorrold 2001), and in most species changes in the diel pattern of aragonite and protein deposition creates daily and annual increments that are apparent following proper preparation (Fowler 1995; Campana 2005). The chemistry of these increments, when combined with the chronological information that is contained within the increments, serves as a permanent archive of ambient environmental characteristics experienced by an individual (Elsdon et al. 2008). Some of the elements in otoliths are deposited in proportion to their concentration in ambient waters (Bath et al. 2000; Elsdon and Gillanders 2005; Walther and 
Thorrold 2006) and remain metabolically inert following deposition (Mugiya et al. 1991). Geochemical analyses of specific growth increments in otoliths can thus be used as an indicator of specific water mass residency at a known point in a fish’s life history.

Natural geochemical signatures in otoliths have been used to assign natal origins in a number of marine fish populations (e.g., Campana et al. 1994; Gillanders and Kingsford 2000; Thorrold et al. 2001). Profiles of an individual's dispersal history can be derived from otolith information and subsequently used to discriminate potential source populations or locations (FitzGerald et al. 2004; Sandin et al. 2005; Hamilton et al. 2008). These studies operate on the premise that fish experiencing differences in temperature and water chemistry will have respective variations in the chemical composition of their otoliths, ideally allowing for otoliths to act as a permanent record of a larval fish’s dispersal (Hoffman and Gaines 2008). For coral reef fishes, serveral studies have found differences in otolith geochemistry among individuals within a population that potentially arrived from different natal sources (e.g., Swearer et al. 1999; Patterson et al. 2004; Hamilton et al. 2008). However, inferring transport pathways from otolith geochemistry is often problematic because it is difficult to generate $a$ priori predictions of the elemental profiles likely to be generated during different dispersal histories (Warner et al. 2005). Mapping or hindcasting the chemistry of water masses potentially encountered by reef fish larvae is a daunting task (e.g., Ben-Tzvi et al. 2008). Finally, it is difficult to reconstruct ambient conditions experienced by larval fish if the potential effect of ontogeny on elemental profiles in otoliths are unknown (Elsdon and Gillanders 2005). These issues have been compounded by the fact that no study has formally tested the assignment accuracy of their geochemical signatures with larvae of known dispersal history. 
As part of an intensive larval retention and connectivity study in a population of the orange clownfish, Amphiprion percula, from Kimbe Island, Papua New Guinea, we determined parents of newly settled recruits using microsatellite DNA genotyping (Planes et al. 2009). The genetic parentage analyses provided a sample of recently settled juveniles for which approximately 50\% could be assigned to parents on the study reef and were therefore of known origin. Because we sampled all of the adults on Kimbe Island, the remainder of the recruits were assumed to be immigrants spawned on reefs at least $10 \mathrm{~km}$ away, the nearest other source populations of $A$. percula. The purpose of this study was to compare characteristics of individuals that settled on their natal reef ("self-recruiters”) versus larvae whose exact natal origins are unknown but are known to be from at least $10 \mathrm{~km}$ away (“immigrants”). Based on other results from coral reef fishes (e.g., Swearer et al. 1999; Hamilton et al. 2008), we hypothesized that pelagic larval duration, otolith growth rate during the larval phase, and elemental profiles in otoliths of the juvenile clownfish may vary with dispersal history, although we were unable to generate specific expectations from our study area. Identifying reliable methods for documenting and understanding connectivity patterns in coral reef fishes, especially larval dispersal, is a pressing problem (McCook et al. 2009), and this study provided an opportunity to cross-validate a new method (genetic parentage analysis) with a more time- and cost-efficient method (otolith chemistry).

\section{Materials and methods}

Newly settled A. percula were collected from anemones around Kimbe Island, Papua New Guinea (05 $12.112^{\prime}$ S, $150^{\circ} 22.881^{\prime}$ E) (Figure 1) in December, 2004. All Heteractis and Stachadactyla anemones on Kimbe Island were mapped and checked by divers on SCUBA 
for the presence of $A$. percula. When present, the largest two A. percula (representing the breeding pair, see Fricke 1979) on each anemone were captured using hand nets. Each fish was measured to the nearest mm and a small piece of fin tissue was clipped from the caudal fin and preserved in a $3 \mathrm{ml}$ vial of $80 \%$ ethanol. If any juvenile $(<4 \mathrm{~cm}) A$. percula were present, they were collected using hand nets and a clove oil mixture. Total length (TL) of the juveniles was measured to the nearest $\mathrm{mm}$.

Genetic parentage analysis was conducted for all the juvenile anemonefishes collected. Using 17 polymorphic microsatellite loci, individual juveniles were genotyped. These unique genotypes were then screened against all reproductive pairs (i.e., the pool of potential parents on Kimbe Island) sampled in the anemones at the same time of the recruit collection. The program FAMOZ (Gerber et al. 2003) was used to compare genotypes of the new recruits against the pool of potential parents. This program allows us to assign parentage to recruits spawned on Kimbe Island and, by exclusion, to identify recruits that did not have parents on our study reef. Full details of the methodology used in the parentage analysis are presented elsewhere (Planes et al. 2009).

From each individual collected, saggital otoliths were extracted, cleaned in fresh water and dried. One otolith was prepared and aged following Wellington and Victor (1992) and Raventos and Macpherson (2001). The length of the pelagic larval stage for each individual was determined by counting the number of daily rings visible between the core and the settlement mark. Otoliths were measured along their longest radius $(\mu \mathrm{m})$ from the core to the hatch mark and from the core to the settlement mark using a Zeiss binocular light microscope connected to a digital camera and image analysis system (Progress camera and software) for each individual. As a proxy for comparing relative growth rate among individuals, the average 
daily growth of individual otoliths during the pelagic larval phase was calculated and compared between groups using ANOVA.

The second otolith from each juvenile was analyzed using laser ablation inductively coupled plasma mass spectrometry (ICP-MS). Otoliths were rinsed in ultrapure water and mounted on petrographic slides using cyanoacrylic glue. Each otolith was ground to the midplane (approximately $5 \mu \mathrm{m}$ from the nucleus) using $3 \mu \mathrm{m}$ lapping film. After triple-rinsing with ultrapure water, otoliths were then dried in a class-100 laminar flow hood for $24 \mathrm{~h}$. Otoliths were then remounted on petrographic slides using double-sided tape for Ba isotope analysis using a New Wave Research UP213 laser ablation system coupled to a ThermoFinnigan Element2 ICP-MS. We tested a number of laser settings to select the optimal balance between horizontal and vertical resolution on otolith sections and count rates of isotopes of interest. To get sufficient spatial resolution on the order of 1-2 days while also avoiding drilling too deeply into the otolith, we used a beam diameter of $10 \mu \mathrm{m}$, laser power at $60 \%$ and a repetition rate of $5 \mathrm{~Hz}$. However, with these conditions, a number of isotopes including ${ }^{25} \mathrm{Mg},{ }^{55} \mathrm{Mn}$, and ${ }^{208} \mathrm{~Pb}$ were below reliable detection limits. Therefore only $\mathrm{Ca}$, Ba, and $\mathrm{Sr}$ were measured on four spots in a transect moving from the center of each otolith towards the outer edge (Figure 2a). The first was centered on the otolith core, the second and third were located in the presettlement material (i.e., between the core and the settlement mark), and the fourth was located in the postsettlement material (i.e., beyond the settlement mark). A He gas stream then carried ablated material to the ICP-MS where it was mixed with an Ar sample gas and a wet aerosol $\left(2 \% \mathrm{HNO}_{3}\right)$ supplied by a self-aspirating $\left(20 \mathrm{~m} \bullet \mathrm{min}^{-1}\right)$ PFA nebulizer in the concentric region of the quartz dual inlet spray chamber. Instrument blanks $\left(2 \% \mathrm{HNO}_{3}\right)$ and a otolith certified reference (Sturgeon et al. 2005), dissolved in $2 \% \mathrm{HNO}_{3}$ and diluted to a final 
Ca concentration of $8 \mu \mathrm{g}^{*} \mathrm{~g}^{-1}$, were run every five samples and used to correct for blankcorrect raw intensities and instrument mass bias, respectively, following FitzGerald et al. (2004). We estimated external precision (relative standard deviation) of the $\mathrm{Sr} / \mathrm{Ca}$ and $\mathrm{Ba} / \mathrm{Ca}$ analyses by running a powdered otolith lab standard, dissolved in $2 \% \mathrm{HNO}_{3}$ and diluted to a Ca concentration of $8 \mu g^{*} g^{-1}$, at the beginning and end of each slide. Estimates $(n=24)$ were 0.35\% and 3.8\% for $\mathrm{Sr} / \mathrm{Ca}$ and $\mathrm{Ba} / \mathrm{Ca}$, respectively.

To test for differences in otolith composition, elemental ratios $(\mathrm{Sr} / \mathrm{Ca}$ and $\mathrm{Ba} / \mathrm{Ca})$ of individual otoliths were compared between the two groups of fish (known self-recruiting juveniles and immigrant juveniles) using a profile analysis (Johnson and Wichern 2007). In this analysis, we first tested whether the curves that describe ratios over the three positions differed for the two fish groups. This hypothesis was tested with the interaction term between fish group and position in a single factor repeated measures analysis MANOVA with fish group (self-recruit or immigrant) as a single factor. If the curves were found to be parallel, coincidence of the curves was tested by comparing the mean of the ratios between the two fish groups taken over the three positions. If the curves were not parallel, paired comparisons (contrasts) were done to determine, for each fish group, which positions had different ratios and within each position whether mean ratios differed between the two fish types. A Bonferonni adjusted alpha-level was used to test for significance of the seven paired contrasts (adjusted alpha-level $=0.007$ ). To homogenize variances, both $\mathrm{Sr} / \mathrm{Ca}$ and $\mathrm{Ba} / \mathrm{Ca}$ ratios were $\mathrm{ln}$ transformed after multiplying the data by $10^{3}$. One fish was deleted from each group because the value of $\mathrm{Ba} / \mathrm{Ca}$ for the second position was exceedingly high, indicating that the sample was taken too near position 1 . All analyses were done using SYSTAT 10.2 in the GLM module. 
In order to understand the extent to which patterns in larval otolith chemistry are ontogenetic as opposed to environmental, we investigated ontogenetic patterns in otolith chemistry by rearing larval $A$. percula in the laboratory under conditions of constant temperature and salinity. Ten pairs of adult $A$. percula were kept in plastic aquaria $(100 \mathrm{~L})$ in an open water system with constant water flow, constant aeration, controlled temperature (29$30^{\circ} \mathrm{C}$ ), controlled $\mathrm{pH}(8.0)$ and controlled salinity (30-32 ppt) at the Marine and Aquaculture Research Facilities Unit of James Cook University in Townsville, Australia. The tanks containing breeding pairs were supplied with a terracotta pot plant holder, two bricks and an anemone (Heteractis crispa or H. magnifica) to create a suitable habitat for breeding and to provide a removable surface for egg laying. Larvae from a single clutch were hatched and grown under the constant conditions of $29-30^{\circ} \mathrm{C}$ temperature and $30-32$ ppt salinity. At the end of ten days, five randomly chosen larvae were sacrificed and their otoliths were removed. The otoliths were prepared and analyzed using ICP-MS in the same manner as described above, with the exception that five spots were sampled on each otolith, one centered on the core and four sequentially moving outwards towards the edge of the otolith (Fig. 2b). A oneway repeated measures analysis of variance was done to test whether the mean ratios of $\mathrm{Sr} / \mathrm{Ca}$ or $\mathrm{Ba} / \mathrm{Ca}$ differed between positions. Pairwise comparisons (contrasts) were done to determine which positions differed, and a Bonferroni adjusted alpha-level of 0.005 was used to determine significance for each pairwise comparison between position means of the ratios. Both $\mathrm{Sr} / \mathrm{Ca}$ and $\mathrm{Ba} / \mathrm{Ca}$ ratios were ln transformed prior to analysis to homogenize variances. All analyses were done using SYSTAT 10.2 using the GLM module.

\section{Results}


A total of 110 juvenile clownfish collected on Kimbe Island were screened in the parentage analysis. Of these, 46 were assigned to parents on Kimbe Island (hereafter termed "selfrecruiters") and the remaining 64 were classified as “immigrants” that arrived from another reef (at least $10 \mathrm{~km}$ away).

Pelagic larval duration (PLD) was determined in 103 larval A. percula, (41 selfrecruiting individuals and 62 immigrant individuals). The mean PLD of self-recruiters (9.8 days \pm 0.1 S.E.) and immigrants (10.0 days \pm 0.1 S.E.) did not vary significantly (ANOVA, df $=1 / 102, F=1.473, P=0.228)$. Likewise, mean otolith deposition rates of self-recruiting individuals (7.8 $\mu$ m.day ${ }^{-1} \pm 0.3$ S.E.) were not significantly different from deposition rates of immigrants (8.3 $\mu$ m.day ${ }^{-1} \pm 0.2$ S.E.) (ANOVA, $d f=1 / 102, F=2.67, P=0.105$ ).

We detected variable ontogenetic effects in larvae reared in the lab under constant

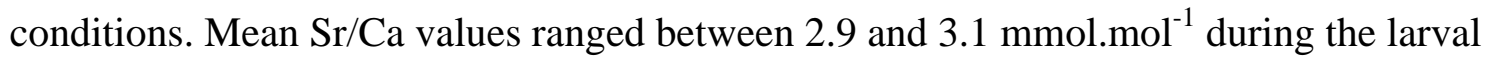
period (Figure 3a), and although $\mathrm{Sr} / \mathrm{Ca}$ ratios differed significantly among positions $\left(\mathrm{F}_{4,36}=\right.$ 3.218, $\mathrm{p}=0.023$ ), no pairwise comparison was significant at the Bonferroni adjusted alpha level of 0.005. Mean Ba/Ca values ranged between 2 and $18 \mu \mathrm{mol} . \mathrm{mol}^{-1}$, but with a pronounced ontogenetic trend (Figure 3b). The Ba/Ca ratios differed significantly over the positions $\left(\mathrm{F}_{4,36}=47.545, \mathrm{p}<0.001\right)$. Mean $\mathrm{Ba} / \mathrm{Ca}$ at the first otolith position was significantly higher than the concentration in any of the other four positions (Bonferroni adjusted post-hoc paired comparisons, $\mathrm{p}<0.005$ ). Mean Ba/Ca ratios did not differ among the other four positions.

We found no detectable differences between elemental profiles of otoliths from larvae returning to settle on reefs around Kimbe Island and those immigrating from more distant reefs. Although elemental profile analysis of Sr/Ca levels from otoliths revealed that the 
curves for the two groups were not parallel (Wilks' Lambda $=0.940, \mathrm{~F}_{2,105}=3.338, \mathrm{p}=$ 0.039), post hoc paired-comparison analysis with Bonferroni adjusted alpha-level did not reveal any significant differences between the curves of the two fish groups. For both fish groups, the mean Sr/Ca ratio was significantly higher at position 1 than in position 2 (Immigrants: $F_{1,62}=53.743, p<0.001$; Self-Recruiters: $F_{1,44}=27.388, p<0.001$ ) whereas $\mathrm{Sr} / \mathrm{Ca}$ ratios at position 2 were not significantly different from Position 3 (Immigrants: $\mathrm{F}_{1,62}=$ 6.484, $\mathrm{p}=0.013$; Self-Recruiters: $\left.\mathrm{F}_{1,44}=0.914, \mathrm{p}=0.344\right)$. Furthermore, $\mathrm{Sr} / \mathrm{Ca}$ ratios did not differ between the two fish groups at any otolith position (Position 1: $\mathrm{F}_{1,106}=0.061, \mathrm{p}=$ 0.806; Position 2: $F_{1,106}=3.699, p=0.057$; Position 3: $F_{1,106}=1.751, p=0.189$ ).

The $\mathrm{Ba} / \mathrm{Ca}$ curves for the two fish groups were not significantly different from parallel (Wilks' Lambda $\left.=0.964, \mathrm{~F}_{2,105}=1.956, \mathrm{p}=0.147\right)$. The curves were likewise found to be coincident, that is, the overall mean $\mathrm{Ba} / \mathrm{Ca}$ ratio of the two fish groups were not significantly different $\left(\mathrm{F}_{1,106}=0.044, \mathrm{p}=0.834\right)$. For both fish groups, $\mathrm{Ba} / \mathrm{Ca}$ ratios were significantly higher at position 1 than at position 2, but ratios did not differ between positions 2 and 3 (Wilks’ Lambda $\left.=0.320, \mathrm{~F}_{2,105}=111.670, \mathrm{p}<0.001\right)($ Contrast results - Self recruiters: position 1 vs 2, $\mathrm{F}_{1,44}=66.141, \mathrm{p}<0.001$; position 2 vs $3, \mathrm{~F}_{1,44}=10.777, \mathrm{p}=0.002$; Immigrants: position 1 vs 2, $\mathrm{F}_{1,62}=134.147, \mathrm{p}<0.001$; position 2 vs $3, \mathrm{~F}_{1,44}=3.683, \mathrm{p}=$ 0.060).

In addition to examining the individual elemental profiles, we looked for clustering that may indicate isolated groupings of individuals potentially indicating distinct sources. However, when plotted individually, the comparisons of individual measurements of $\mathrm{Sr} / \mathrm{Ca}$ vs. Ba/Ca ratios did not reveal any unique groupings of immigrants distinct from the selfrecruiting individuals (Figure 5). 


\section{Discussion}

We assessed the ability of geochemical signatures in otoliths to record larval dispersal histories of known-origin orange clownfish recruits. Natural geochemical signatures are particularly useful tags of natal origins, at least in theory, because they avoid many of the pitfalls encountered by conventional tag-recapture approaches in marine systems (Thorrold et al. 2002). Every individual from a population with a unique geochemical signature is indelibly tagged, and every individual sampled some time after the initial geochemical atlas is constructed represents a recapture (Becker et al. 2005). Larval growth rates and PLDs have also been combined with otolith chemistry analyses to identify likely dispersal pathways of reef fishes (Swearer et al. 1999). To date, however, no study has been able to test the accuracy of geochemical signatures using larvae with known dispersal histories in a marine system. Several recent studies have found comparatively little spatial variation in geochemical signatures among locations in coastal marine environments (Ruttenberg et al. 2008; Standish et al. 2008). Our data were consistent with these latter results; we were unable to detect any differences in larval characteristics or otolith chemistry between self-recruiting larvae and larvae arriving at Kimbe Island from other locations at least $10 \mathrm{~km}$ away. This is not to say that otolith chemistry is not a useful technique for assessing natal origins; our particular study system may not be ideal due to the relatively short PLD of Amphiprion percula or due to the potentially homogeneous water chemistry at the scale these fish may be dispersing (10's of $\mathrm{kms})$.

The parentage data we have for this study allows us to discriminate self-recruiters from immigrants, but it does not allow us to identify groups of immigrants from discrete 
locations (Planes et al. 2009). We are thus only able to compare self-recruiters against an average or pooled group of immigrants. The individual measurements from within the pool of self-recruiters (from one small island) shows the same amount of variability in the core measurements (Figure 5a) as the entire pool of immigrants, so it seems unlikely that immigrants from various locations would show tighter groupings. Without the parentage data, it is unlikely that we could even distinguish self-recruiters from immigrants, much less distinguish groups from other natal origin locations. Further, without water chemistry data, it is not possible to generate expectations of differences in otolith chemistry among potential natal origins.

Prior studies on A. percula at Kimbe Island found as many as $60 \%$ of recruits settling into anemones around the island were the offspring of local parents (Almany et al. 2007; Planes et al. 2009). However, the mechanisms responsible for the high level of local replenishment at Kimbe Island remain unknown. Mesoscale physical features may contribute to enhanced local larval retention (Sponaugle et al. 2002). For example, eddies in the wake of the island at the time of hatching may reduce large-scale dispersal of larvae. Late-stage larval fish are also known to have well-developed visual, olfactory, and auditory senses (Leis and McCormick 2002; Montgomery et al. 2006) that could be used to maintain a position close to the island, presumably cueing to some kind of terrestrial "halo" arising from the island's terrigenous input. A recent study showed that $A$. percula were able to distinguish water containing anemones or rainforest vegetation (Dixson et al. 2008), suggesting that odor plumes from islands may play a role in larval orientation. Water masses containing such odor plumes may also carry other terrigenous chemical signature distinguishing it from waters utilized by larval A. percula from more distant sites. Finally, Kimbe Island also possesses 
several deep enclosed lagoons (Figure 1b) where newly hatched fish from Kimbe Island could possibly spend their entire larval stage, thus never leaving Kimbe Island. These enclosed lagoons are subject to higher sedimentation rates and greater temperature fluctuations than water masses away from the island. Any of these scenarios could potentially result in exposure to different water chemistry for self-recruiting fish larvae than larvae dispersing from distant reefs across open water. We expect that such potential chemical differences would be recorded in otolith aragonite deposited during the larvae phase, but found no evidence that self-recruiting larvae experienced water chemistry different from immigrant larvae. As we were unable to test specific water chemistry in lagoons, near Kimbe Island, or offshore of Kimbe Island, we cannot identify the reason for a lack of a difference.

Despite the potential for otolith chemistry to record larval disperal histories, we found that natural markers cannot be used to discriminate larval origins for A. percula in Kimbe Bay. Without prior knowledge of water chemistry from our study area, and without knowledge of exact natal reefs (or even region) of immigrant larvae, we did not have a priori expectations that otolith chemistry would vary. Presettlement profiles of elemental ratios measured in the otoliths were found to be coincident between otoliths from juveniles dispersing to Kimbe Island from at least $10 \mathrm{~km}$ and in otoliths from juveniles that were born on and subsequently settled on the same island, indicating that the source of the larvae has no distinguishable effect on the profile. Pelagic larval durations, growth rates during the dispersal stage, and $\mathrm{Sr} / \mathrm{Ca}$ and $\mathrm{Ba} / \mathrm{Ca}$ ratios in otoliths were also statistically indistinguishable for both groups of larvae in our study. These findings support two conclusions. First, if self-recruiting larvae at Kimbe Island are using deep lagoons around the island as a means of local retention, the water chemistry does not appear to be different from water offshore. Otherwise, we would 
expect to see marked differences in otolith composition between the two groups. Following from this, an important second conclusion is that self-recruiting larvae were spending their dispersal phase in water masses that could not be distinguished from those experienced by immigrant larvae by using otolith chemistry, PLDs or larval growth rates. It may not be surprising that PLD and larval growth rates do not vary in our sample as there could be relatively little spatial variation in the population (perhaps only 10's of kms) and no reason to suspect differences in environmental conditions usually affecting these characters (e.g., REF). Further, these traits may not be as flexible as they are in other spceies (e.g., REF) and there is clearly a high degree of connectivity among the populations (evidenced by the immigrant numbers). Natural geochemical tags may generally lack sufficient resolution in coral reef fishes inhabiting the waters in our study area during their pelagic larval stages. Fish dispersing among reefs at this scale or in the type of waters found near coral reefs in Kimbe Bay may simply not encounter enough variation in water mass characteristics to produce measurable differences in otolith chemistry. Previous studies have noted that a lack of difference in otolith chemistry does not exclude the possibility of multiple larval sources (e.g., Patterson et al. 2005); our results support this conclusion using genetic parentage techniques to identify the origin of a portion of our larvae (Planes et al. 2009). Again, our lack of knowledge of the specific water chemistry in the Kimbe Island lagoons, near Kimbe Island, and in the water masses at the natal reefs of immigrant larvae prevents us from drawing strong conclusions about the natal origins or dispersal patterns of our immigrant larvae, but it does indicate that traditional use of otolith chemistry in this study system cannot provide greater resolution than a parentage-based approach (Planes et al. 2009). 
Otoliths from larval A. percula reared under constant temeprature and salinity conditions provided a useful measure of ontogenetic variability in otolith chemistry that was not under environmental control. We found that Sr/Ca levels did not vary along profiles from the center to the edge of otoliths from the lab reared larvae. Strontium ions substitute readily for $\mathrm{Ca}$ in the aragonite matrix of otoliths and are derived primarily from the ambient water (Farrell and Campana 1996; Walther and Thorrold 2006). Temperature and water chemistry appear to represent the dominant control on Sr/Ca ratios in otoliths (Bath et al. 2000; Martin et al. 2004). Therefore, the similarity of Sr/Ca profiles between lab-reared and wild-caught individuals suggest that juveniles recruiting to Kimbe Island experienced relatively constant environmental conditions during larval life. However, we noted a clear and consistent ontogenetic effect in $\mathrm{Ba} / \mathrm{Ca}$ ratios, with otolith cores enriched compared to all positions deposited after hatching. Ruttenberg et al. (2005) also noted Ba enrichment in otolith cores from three of the six species that they examined. The observation that enriched Ba isotopes are transferred from mothers to the embryonic otoliths of their offspring (Thorrold et al. 2006) argues strongly for the presence of maternal effects on otolith chemistry. After hatching, $\mathrm{Ba} / \mathrm{Ca}$ profiles in the lab-reared otoliths were constant and in wild larvae otolith $\mathrm{Ba} / \mathrm{Ca}$ ratios may well record differences in water chemistry (Bath et al. 2000; Elsdon and Gillanders 2005). If so, $\mathrm{Ba} / \mathrm{Ca}$ ratios in the otoliths of both self-recruiting juveniles and immigrant fish again showed little evidence of encountering any major changes in environmental conditions duing larval life. This does not mean that otolith chemistry can never be a useful tool for determining larval origin, but it does emphasize that caution needs to be used when the technique is applied to coral reef fishes. 
Patterns of larval dispersal remain a critical knowledge gap for managers of marine resources (Fogarty and Botsford 2007; Jones et al. 2007; McCook et al. 2009). Using otolith chemistry as a natural tag of natal origins works well in habitats with large environmental gradients, including freshwater and estuarine habitats (Thorrold et al. 2001; McCulloch et al. 2005) or coral reef habitats with marked variation in terrigenous and anthropogenic influences (e.g., Ruttenberg et al. 2008). The water experienced by larvae originating or spending time in these environments with marked chemical variation is more likely to result in clear groupings as opposed to the potentially homogenous waters found adjacent to the offshore coral reefs typical in our study area (Kimbe Bay). Identifying techniques capable of providing reliable estimates of connectivity among populations is a pressing need, particularly in coral reef systems, but it is important to test these techniques with more definitive methods (Thorrold et al. 2007), such as tagging or parentage studies (Jones et al. 1999, 2005; Almany et al. 2007; Planes et al. 2009). These genetic- and tagging-based studies, however, are costly and timeconsuming, and may not be feasible for many species or over very large scales. Otolith chemistry, by comparison, can be a much more cost-effective approach, so cross-validation of these methods will be critical as these tools are increasingly applied to studies of population connectivity in marine ecosystems.

\section{Acknowledgements}

The crew of the MV FeBrina and the staff of the Mahonia Na Dari research station provided invaluable logistic support. Discussions with M. Meekan, D. Hogan, and D. Heath, as well as comments from P. Munday and two anonymous reviewers greatly improved the manuscript. Field assistance was provided by C. Hervet, V. Messmer, M. Srinivasan, and C. Syms. The 
Mahonia Na Dari Research and Conservation Centre, Walindi Plantation Resort, The Nature Conservancy, and the crew of M.V. FeBrina provided essential logistic support. We acknowledge the traditional owners for allowing us access to their reefs. Research was supported by the Australian Research Council, the Coral Reef Initiatives for the Pacific (CRISP), the Global Environmental Facility CRTR Connectivity Working Group, the Total Foundation, a National Science Foundation grant (\# 0424688) to SRT, and a National Science Foundation Graduate Research Fellowship to MLB. The authors declare that they have no conflict of interest. 


\section{References}

Almany GR, Berumen ML, Thorrold SR, Planes S, Jones GP (2007) Local replenishment of coral reef fish populations in a marine reserve. Science 316: 742-744

Bath GE, Thorrold SR, Jones CM, Campana SE, McLaren JW, Lam JWH (2000) Strontium and barium uptake in aragonitic otoliths of marine fish. Geochim Cosmochim Acta 64: 1705-1714

Becker BJ, Fodrie FJ, McMillan PA, Levin LA (2005) Spatial and temporal variation in trace elemental fingerprints of mytilid mussel shells: A precursor to invertebrate larval tracking. Limnol Oceanogr 50: 4861

Ben-Tzvi O, Kiflawi M, Gaines SD, Al-Zibdah M, Sheehy MS, Paradis GL, Abelson A (2008) Tracking recruitment pathways of Chromis viridis in the Gulf of Aqaba using otolith chemistry. Mar Ecol Prog Ser 359: 229-238

Campana SE (2005) Otolith science entering the 21st century. Mar Freshw Res 56: 485-495

Campana SE, Thorrold SR (2001) Otoliths, increments, and elements: keys to a comprehensive understanding of fish populations? Can J Fish Aquat Sci 58: 30-38

Campana SE, Fowler AJ, Jones CM (1994) Otolith elemental fingerprinting for stock identification of Atlantic cod (Gadus morhua) using laser ablation ICPMS. Can J Fish Aquat Sci 51: 1942-1950

Cowen RK, Gawarkiewicz G, Pineda J, Thorrold SR, Werner FE (2007) Population connectivity in marine systems: An overview. Oceanography 20: 14-21

Dixson DL, Jones GP, Munday PL, Planes S, Pratchett MS, Srinivasan M, Syms C, Thorrold SR (2008) Coral reef fish smell leaves to find island homes. Proc R Soc B 275: 2831-2839

Elsdon TS, Gillanders BM (2005) Consistency of patterns between laboratory experiments and field collected fish in otolith chemistry: an example and applications for salinity reconstructions. Mar Freshw Res 56: 609-617

Elsdon TS, Wells BK, Campana SE, Gillanders BM, Jones CM, Limburg KE, Secor DE, Thorrold SR, Walther BD (2008) Otolith chemistry to describe movements and life-history measurements of fishes: hypotheses, assumptions, limitations, and inferences using five methods. Oceanogr Mar Biol Annu Rev 46: 297-330

Farrell J, Campana SE (1996) Regulation of calcium and strontium deposition on the otoliths of juvenile tilapia, Oreochromis niloticus. Comp Biochem Physiol A 115: 103-109

FitzGerald JL, Thorrold SR, Bailey KM, Brown AL, Severin KP (2004) Elemental signatures in otoliths of larval walleye pollock (Theragra chalcogramma) from the northeast Pacific Ocean. Fish Bull 102: 604-616

Fogarty MJ, Botsford LW (2007) Population connectivity and spatial management of marine fisheries Oceanography 20: 112-123

Fowler AJ (1995) Annulus formation in the otoliths of coral reef fish: a review. In: Secor DH, Dean JM, Campana SE (eds) Recent developments in fish otolith research. University of South Carolina Press, Columbia, pp 45-63

Fricke HW (1979) Mating system, resource defence and sex change in the anemonefish Amphiprion akallopisos. Z Tierpsychol 50: 313-326

Gaines SD, Gaylord B, Gerber LR, Hastings A, Kinlan BP (2007) Connecting places: The ecological consequences of dispersal in the sea. Oceanography 20: 90-99

Gerber S, Chabrier P, Kremer A (2003) FAMOZ: a software for parentage analysis using dominant, codominant and uniparentally inherited markers. Mol Ecol Notes 3: 479-481

Gillanders BM, Kingsford MJ (2000) Elemental fingerprints of otoliths of fish may distinguish estuarine 'nursery' habitats. Mar Ecol Prog Ser 201: 273-286 
Hamilton SL, Regetz J, Warner RR (2008) Postsettlement survival linked to larval life in a marine fish. Proc Nat Acad Sci USA 105: 1561-1566

Hofmann GE, Gaines SD (2008) New tools to meet new challenges: Emerging technologies for managing marine ecosystems for resilience. BioScience 58: 43-52

Johnson RA, Wichern DW (2007) Applied Multivariate Statistical Analysis (6 ${ }^{\text {th }}$ Edition). Prentice Hall.

Jones GP, Planes S, Thorrold SR (2005) Coral reef fish larvae settle close to home. Curr Biol 15: 1314-1318

Jones GP, Srinivasan M, Almany GR (2007) Population connectivity and conservation of marine biodiversity. Oceanography 20: 42-53

Jones GP, Milicich MJ, Emslie MJ, Lunow C (1999) Self-recruitment in a coral reef fish population. Nature 402: 802-804

Leis JM, McCormick MI (2002) The biology, behavior, and ecology of the pelagic, larval stage of coral reef fishes. In: Sale PF (ed) Coral reef fishes. Academic Press, San Diego, pp 171-199

Levin LA (2006) Recent progress in understanding larval dispersal: new directions and digressions. Integr Comp Biol 46: 282-297

Martin GB, Thorrold SR, Jones CM (2004) Temperature and salinity effects on strontium incorporation in otoliths of larval spot (Leiostomus xanthurus). Can J Fish Aquat Sci 61: 34-42

McCook LJ, Almany GR, Berumen ML, Day JC, Green AL, Jones GP, Leis JM, Planes S, Russ GR, Sale PF, Thorrold SR (2009) Management under uncertainty: guide-lines for incorporating connectivity into the protection of coral reefs. Coral Reefs 28: 353-366

McCulloch M, Cappo M, Aumend J, Müller W (2005) Tracing the life history of individual barramundi using laser ablation MC-ICP-MS Sr-isotopic and Sr/Ba ratios in otoliths. Mar Freshw Res 56: 637-644

Montgomery JC, Jeffs A, Simpson SD, Meekan MG, Tindle C (2006) Sound as an orientation clue for the pelagic larvae of reef fish and crustaceans. Adv Mar Biol 51: 143-196

Mugiya Y, Hakomori T, Hatsutori K (1991) Trace metal incorporation into otoliths and scales in the goldfish, Carassius auratus. Comp Biochem Phys C 99C: 327-331

Patterson HM, Kingsford MJ, McCulloch MT (2004) Elemental signatures of Pomacentrus coelestis otoliths at multiple spatial scales on the Great Barrier Reef, Australia. Mar Ecol Prog Ser 270: 229-239

Patterson HM, Kingsford MJ, McCulloch MT (2005) Resolution of the early life history of a reef fish using otolith chemistry. Coral Reefs 24: 222-229

Planes S, Jones GP, Thorrold SR (2009) Larval dispersal connects fish populations in a network of marine protected areas. Proc Nat Acad Sci USA 106: 5693-5697

Ralston S (1976) Age determination of a tropical reef butterflyfish utilizing daily growth rings of otiliths. US Fish Bull 74: 990-994

Raventos N, Macpherson E (2001) Planktonic larval duration and settlement marks on the otoliths of Mediterranean littoral fishes. Mar Biol 138:1115-1120

Ruttenberg BI, Hamilton SL, Warner RR (2008) Spatial and temporal variation in the natal otolith chemistry of a Hawaiian reef fish: prospects for measuring population connectivity. Can J Fish Aquat Sci 65: 1181-1192

Ruttenberg BI, Haupt AJ, Chiriboga AI, Warner RR (2005) Patterns, causes and consequences of regional variation in the ecology and life history of a reef fish. Oecologia 145: 394-403

Sandin SA, Regetz J, Hamilton SL (2005) Testing larval fish dispersal hypotheses using maximum likelihood analysis of otolith chemistry data. Mar Freshw Res 56: 725-734

Sponaugle S, Cowen RK, Shanks A, Morgan SG, Leis JM, Pineda J, Boehlert GW, Kingsford MJ, Lindeman K, Grimes C, Munro JL (2002) Predicting self-recruitment in marine populations: Biophysical correlates and mechanisms. Bull Mar Sci 70S: 341-375 
Standish JD, Sheehy M, Warner RR (2008) Use of otolith natal elemental signatures as natural tags to evaluate connectivity among open-coast fish populations. Mar Ecol Prog Ser 356: 259-268

Sturgeon RE, Willie SN, Yang L, Greenberg R, Spatz RO, Chen Z, Scriver C, Clancy V, Lam JW, Thorrold SR (2005) Certification of a fish otolith reference material in support of quality assurance for trace element analysis. J Anal At Spectrom 20: 1067-1071

Swearer SE, Caselle JE, Lea DW, Warner RR (1999) Larval retention and recruitment in an island population of a coral-reef fish. Nature 402: 799-802

Thorrold SR, Zacherl DC, Levin LA (2007) Population connectivity and larval dispersal using geochemical signatures in calcified structures. Oceanography 20: 80-89

Thorrold SR, Jones GP, Planes S, Hare JA (2006) Transgenerational marking of embryonic otoliths in marine fishes using barium stable isotopes. Can J Fish Aquat Sci 63: 1193

Thorrold SR, Latkoczy C, Swart PK, Jones CM (2001) Natal homing in a marine fish metapopulation. Science 291: 297-299

Thorrold SR, Jones GP, Hellberg ME, Burton RS, Swearer SE, Neigel JE, Morgan SG, Warner RR (2002) Quantifying larval retention and connectivity in marine populations with artificial and natural markers. Bull Mar Sci 70: S291-S308

Walther BD, Thorrold SR (2006) Water, not food, contributes the majority of strontium and barium deposited in the otoliths of a marine fish. Mar Ecol Prog Ser 311: 125-130

Warner RR, Swearer SE, Caselle JE, Sheehy M, Paradis G (2005) Natal trace-elemental signatures in the otoliths of an open-coast fish. Limnol Oceanogr 50: 1529-1542

Wellington GM, Victor BC (1992) Regional differences in duration of the planktonic larval stage of reef fishes in the eastern Pacific Ocean. Mar Biol 113:491-498

Zacherl DC, Manríquez PH, Paradis G, Day RW, Castilla JC, Warner RR, Lea DW, Gaines SD (2003) Trace elemental fingerprinting of gastropod statoliths to study larval dispersal trajectories. Mar Ecol Prog Ser 248: 297-303 
Figure 1. (a) Map of the study region, Kimbe Bay, West New Britain, Papua New Guinea, showing the specific study site, Kimbe Island (yellow circle), in relation to the nearest reefs (red circles) with populations of the study species, Amphiprion percula. (b) Aerial photo of Kimbe Island and its surrounding reef showing the prominent deep (up to $18 \mathrm{~m}$ ) enclosed lagoons around the island.

Figure 2. Example of an Amphiprion percula otolith sampled along a transect of developmental stages. (a) Four 10- $\mu$ m-diameter spots were ablated and elemental composition assessed using laser ablation ICP-MS in otoliths of newly settled juveniles collected at Kimbe Island, PNG. Arrows indicate typical spot positioning: 1) core material; 2) early presettlement stage; 3) late presettlement stage; 4) post-settlement stage. (b) Five 10- $\mu$ mdiameter spots were assessed in larvae reared in controlled temperature conditions in aqauria. Arrows indicate typical spot positioning: 1) core material; 2 to 5) presettlement stages moving sequentially outward from the core towards the edge of the otolith.

Figure 3. Elemental composition measured using laser ablation ICP-MS at five positions (see Figure 2b) in otoliths of larval Amphiprion percula reared in controlled conditions: (a) Mean $\mathrm{Sr} / \mathrm{Ca}$ ratio $(\mathrm{mmol} / \mathrm{mol} \pm \mathrm{SE})$ and $(\mathrm{b}) \mathrm{Mean} \mathrm{Ba} / \mathrm{Ca}$ ratio $(\mu \mathrm{mol} / \mathrm{mol} \pm \mathrm{SE})$.

Figure 4. Mean ( $\pm \mathrm{SE}$ ) Sr/Ca ratios (mmol/mol) (a) and mean $( \pm \mathrm{SE}) \mathrm{Ba} / \mathrm{Ca}$ ratios ( $\mu \mathrm{mol} / \mathrm{mol}$ ) (b) measured using laser ablation ICP-MS at four positions (see Figure 2a) in otoliths of Amphiprion percula juveniles returning to natal reefs around Kimbe Island (solid lines) and A. percula juveniles settling on anemones around Kimbe Island after dispersing from other locations (dashed lines). 
Figure 5. Scatterplots of individual values for $\mathrm{Sr} / \mathrm{Ca}(\mathrm{mmol} / \mathrm{mol}$ ) (x-axis) vs. $\mathrm{Ba} / \mathrm{Ca}$ ( $\mu \mathrm{mol} / \mathrm{mol})$ (y-axis) ratios measured using laser ablation ICP-MS for immigrant (gray circles) and self-recruiting (black diamonds) A. percula individuals at three positions in their otoliths: a) values from the core positions, b) values from early pelagic larval stage, and c) values from late pelagic larval stage. 

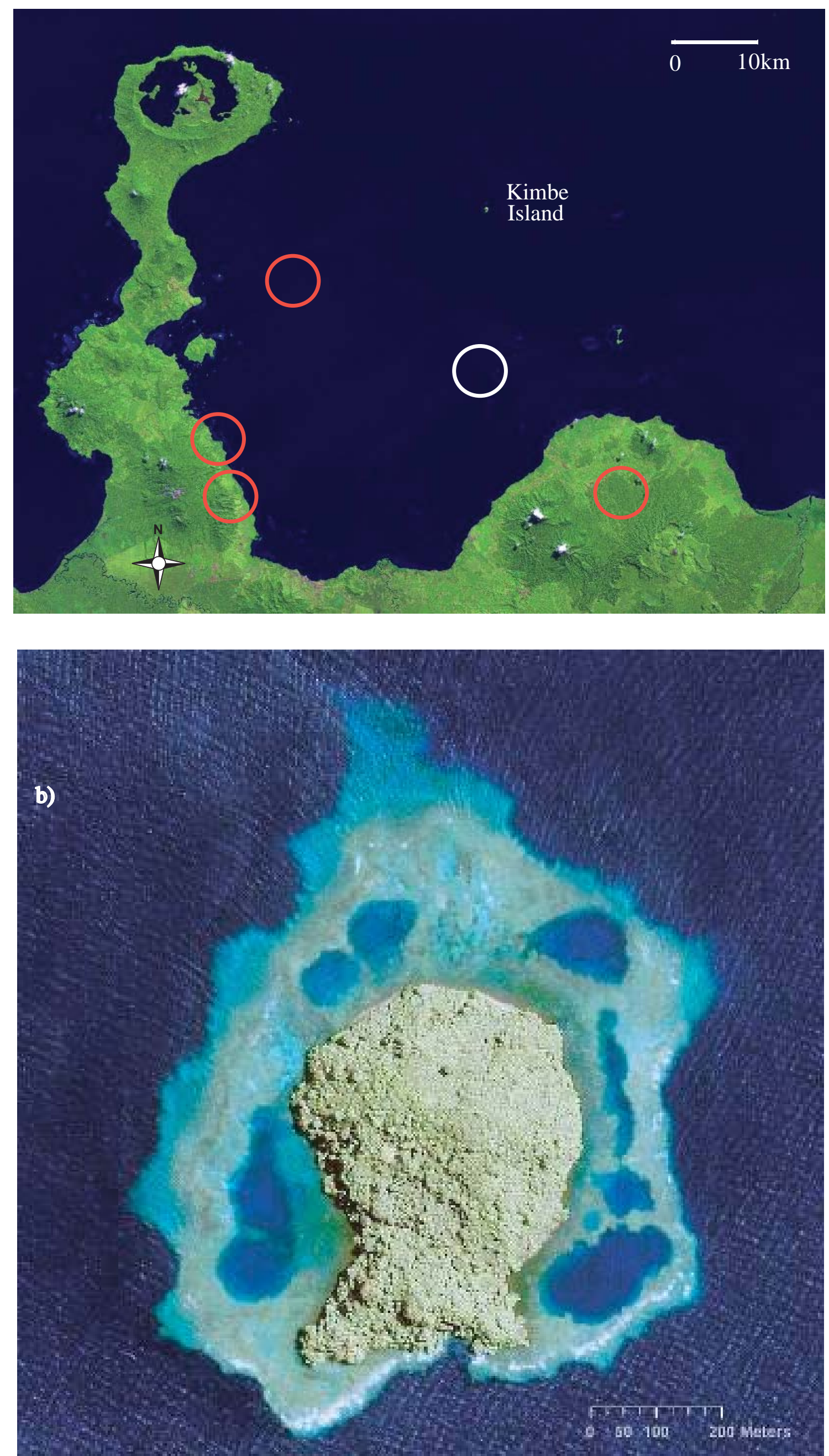


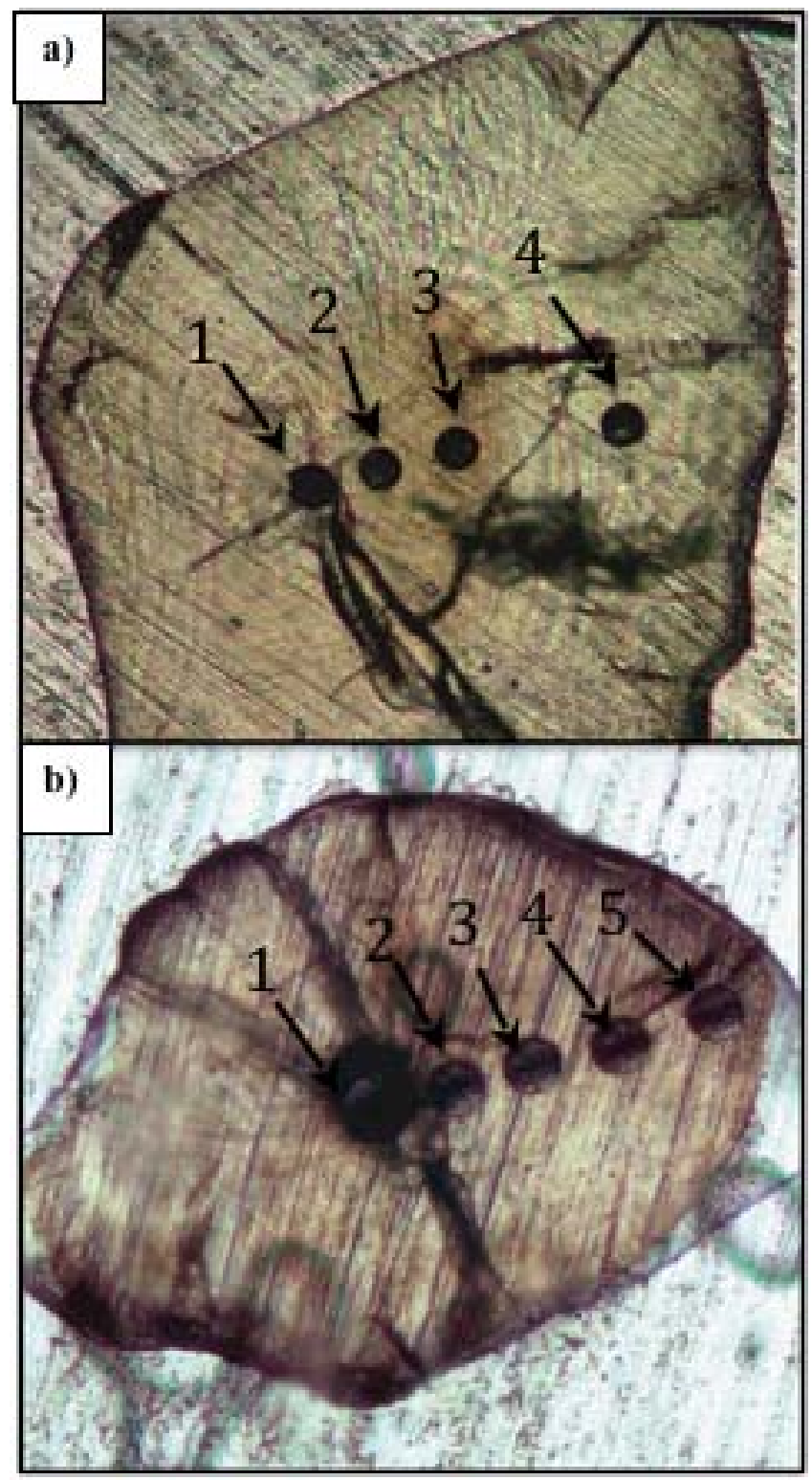


Figure 3
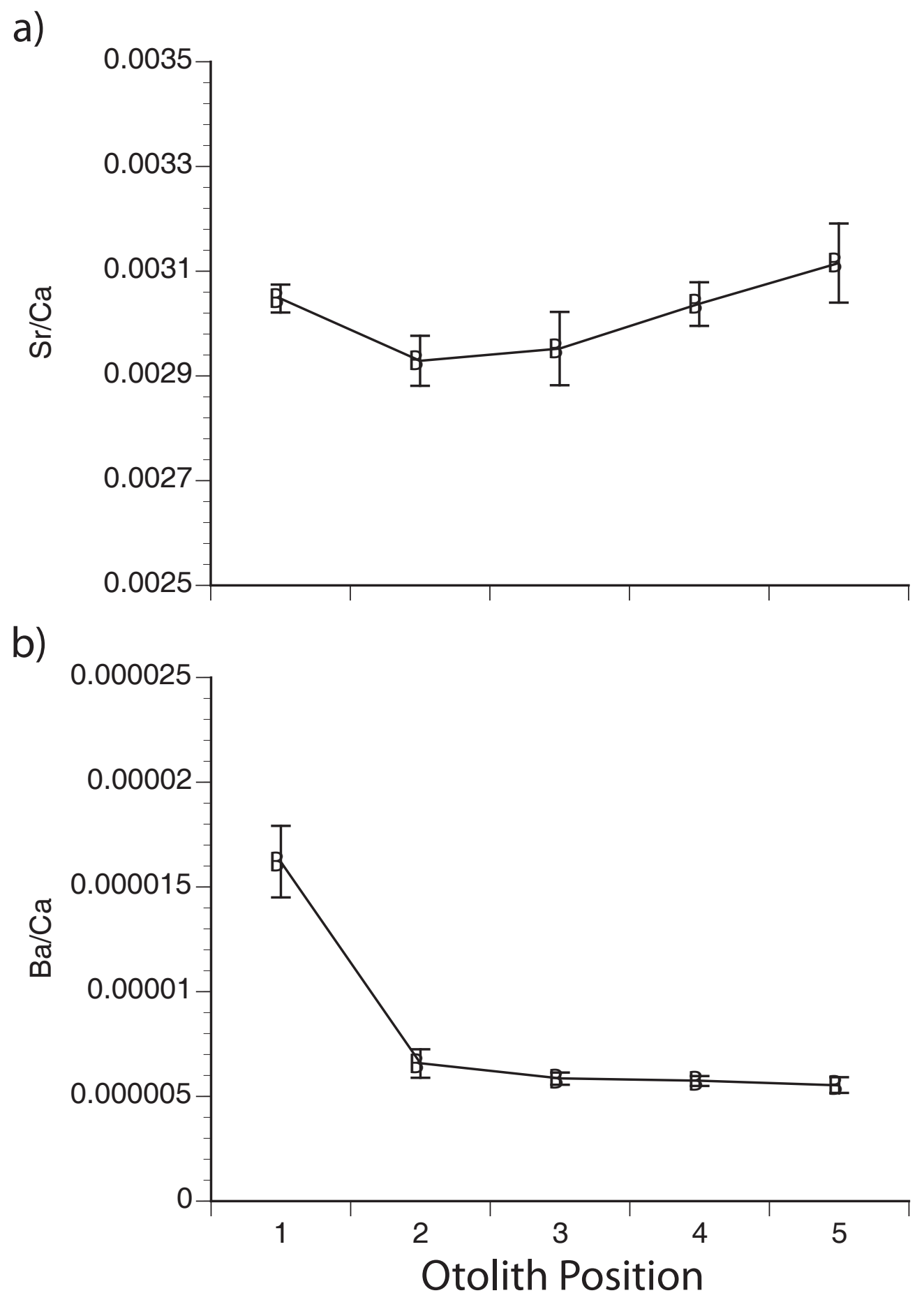
Figure 4

a)

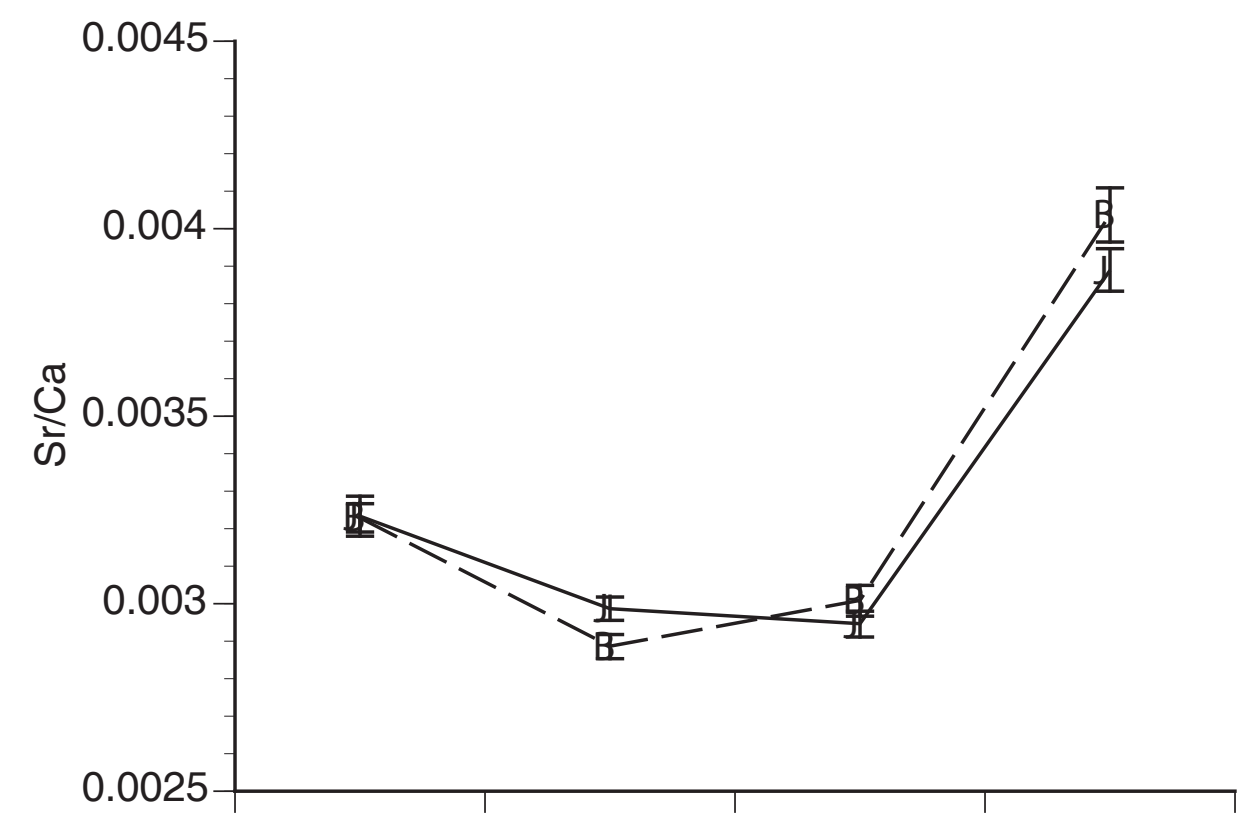

b)

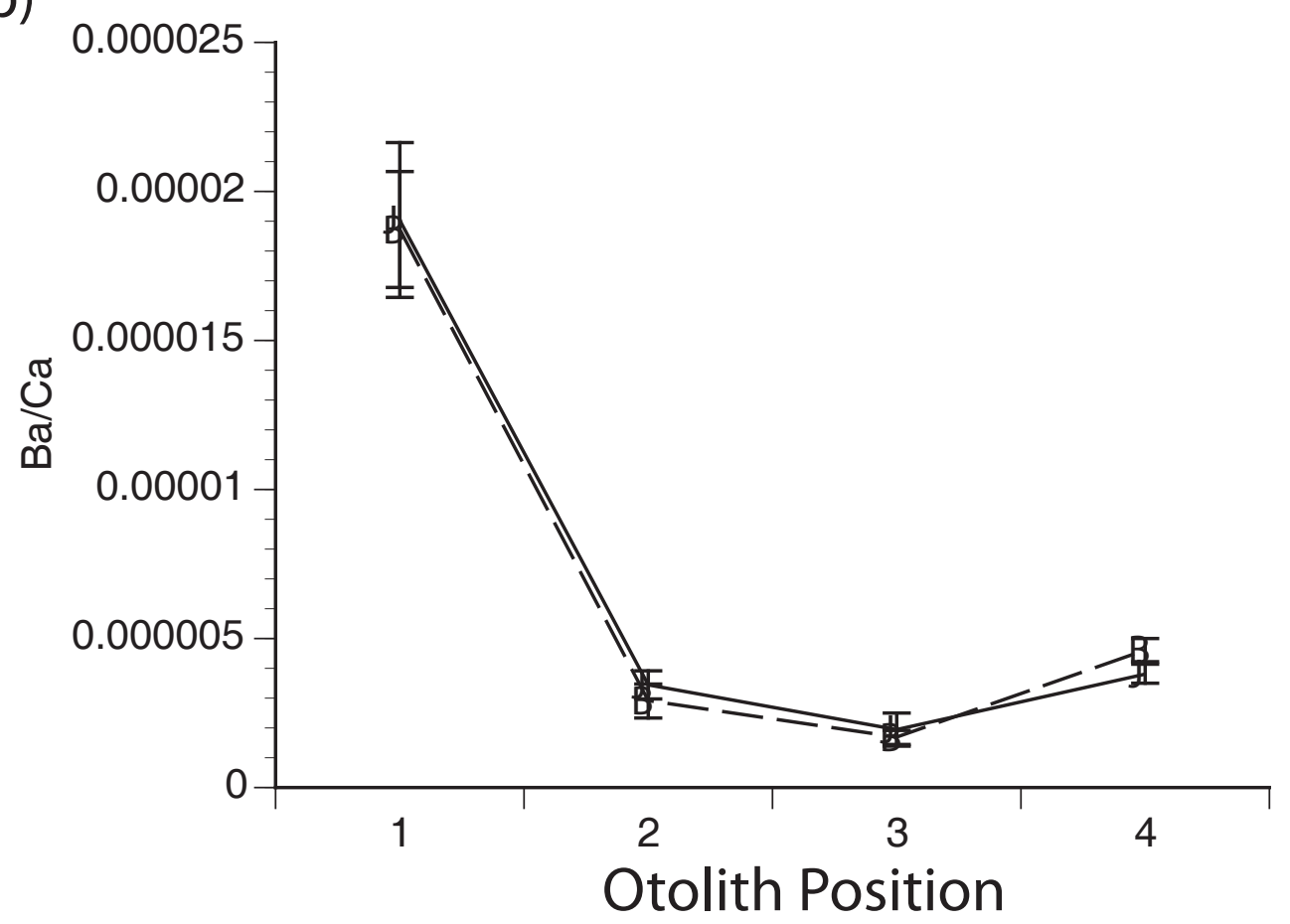


Figure 5

a)

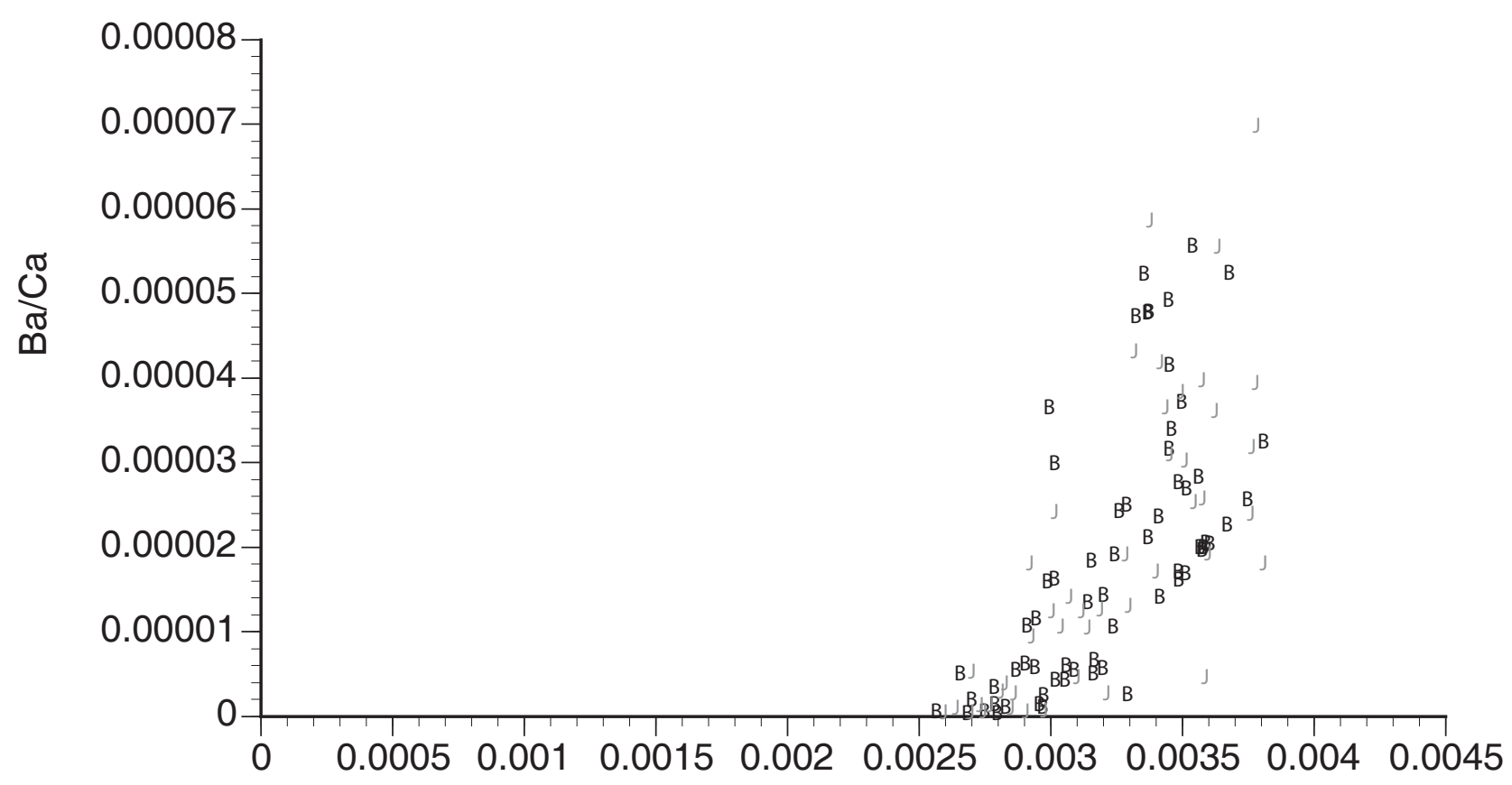

b)

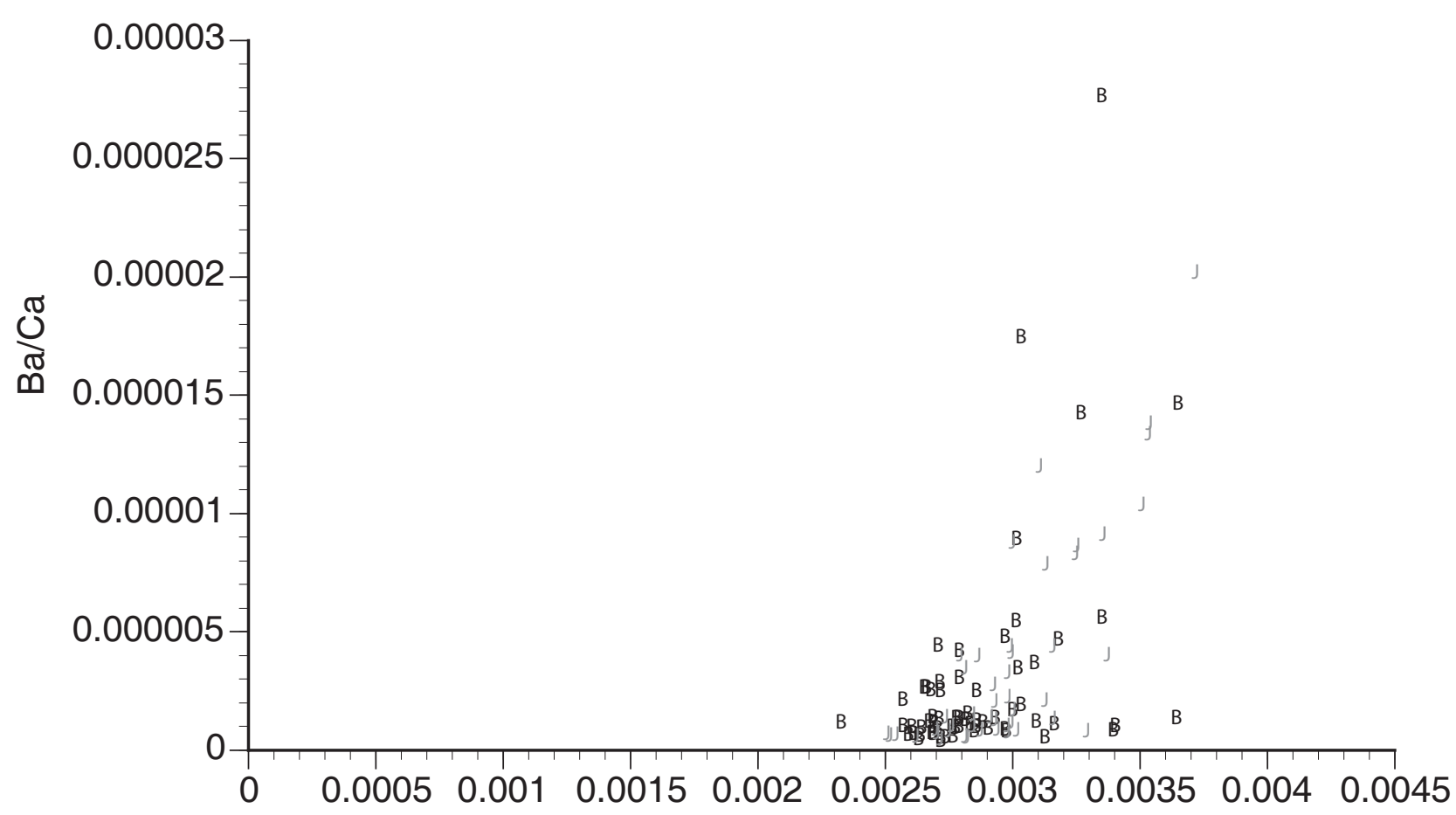

C)

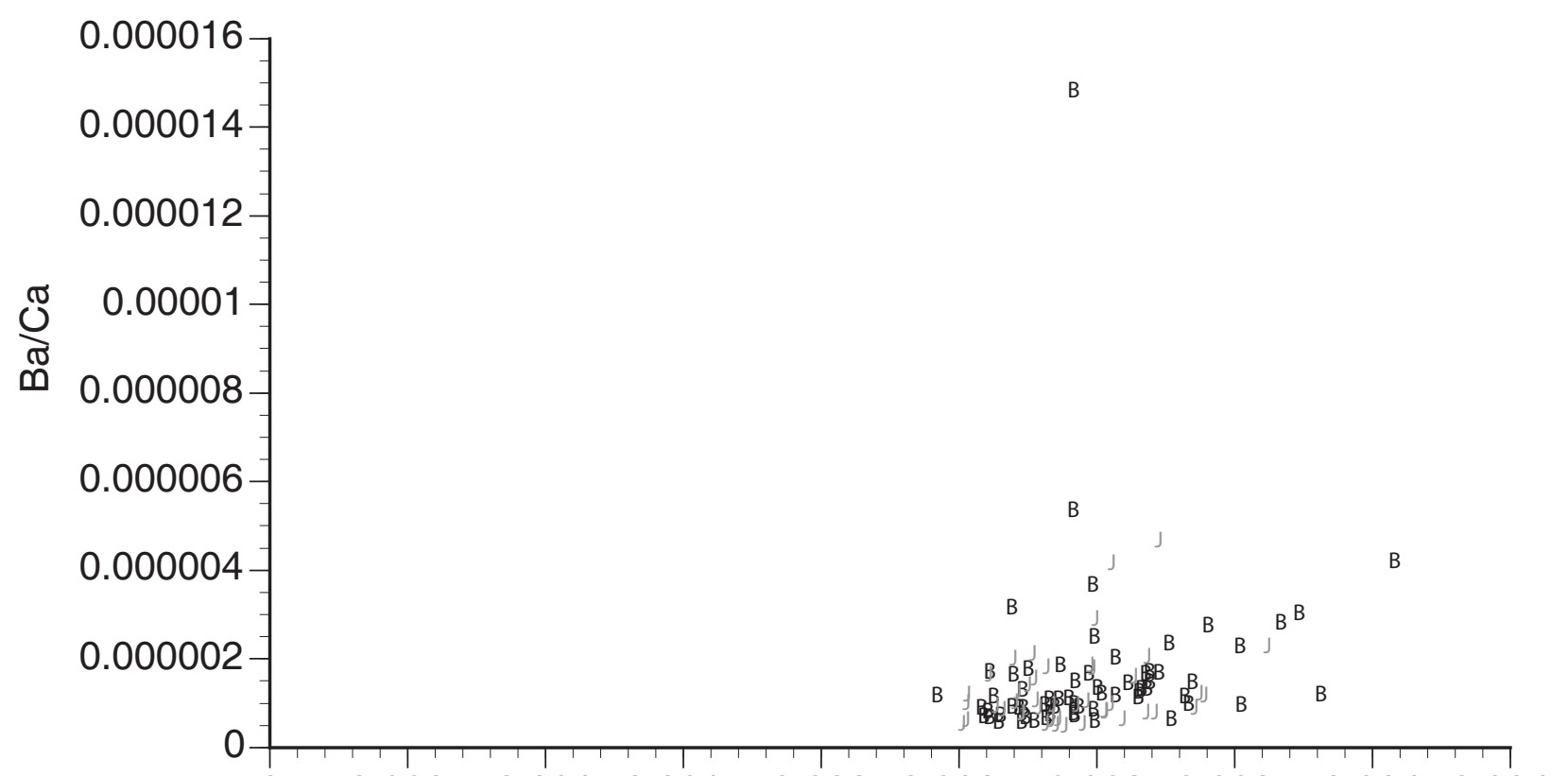

